\title{
Cervical Cancer Screening: Defining the Need for Research
}

\section{Früherkennung des Zervixkarzinoms: den Forschungsbedarf definieren}

Authors

Affiliations
E. Simoes ${ }^{1}$, S. Brucker², M. W. Beckmann ${ }^{3}$, O. Ortmann ${ }^{4}$, C. Albring ${ }^{5}$, D. Wallwiener ${ }^{6}$

The affiliations are listed at the end of the article

\section{Key words}

- cervical cancer

- cervical intraepithelial neoplasia (CIN)

- gynaecology

- screening

Schlüsselwörter

- Zervixkarzinom

- Zervixpräkanzerose

- Gynäkologie

- Screening received 29.1.2013

revised 29.1.2013

accepted 1.2.2013

\section{Bibliography}

Dol http://dx.doi.org/

10.1055/s-0032-1328303

Geburtsh Frauenheilk 2013; 73:

239-246 ๔ Georg Thieme

Verlag KG Stuttgart · New York

ISSN 0016-5751

Correspondence

Prof. Elisabeth Simoes,

Dr. med.

Universitätsfrauenklinik

Tübingen

Institut für Frauen-

gesundheitsforschung

72076 Tübingen

elisabeth.simoes@

med.uni-tuebingen.de

\section{Abstract \\ $\nabla$}

With the development of a National Cancer Plan published in 2012, Germany has followed the recommendations of the WHO and the EU. The first area of action listed in Germany's National Cancer Plan is improving the early detection of cancer. Both citizens and medical specialists are encouraged to take responsibility themselves and contribute to the efforts being made to meet the challenge of cancer. Screening for cervical cancer has long been an integral part of the German Directive for the Early Detection of Cancer and now following the recommendations given in the European Guideline - an organised screening approach shall be developed to maximise the benefits and minimise the risks through a partial reorganisation of existing structures. Before this can be rolled out nationwide, it will be necessary to check the feasibility and suitability of new contents and organisational structures. The Federal Joint Committee which is largely responsible for the process according to the draft law on the implementation of the National Cancer Plan has emphasised the importance of evidence-based medicine and of collaboration between the autonomous governing bodies within the healthcare system to obtain viable results. For medical specialists, the follow-on question is which areas will need more research in future. New process steps need to be developed and verified to see whether they offer evidence which will support defined approaches or whether such evidence needs to be newly compiled, e.g. by testing invitation procedures for screening in trial schemes. The experience gained during the implementation of the existing directive on early detection of cancer should be integrated into the new process. Research initiated by specialists could encourage the development of a new version of the Directive for the Early Detection of Cancer suitable for the Germany's healthcare system.

\section{Zusammenfassung \\ $\nabla$}

Mit der Entwicklung des 2012 veröffentlichten Nationalen Krebsplans folgte Deutschland den Empfehlungen von WHO und EU. An erster Stelle der Handlungsfelder im Nationalen Krebsplan steht die Weiterentwicklung der Krebsfrüherkennung. Bürger/-innen sind zur selbstverantwortlichen Beteiligung an den Anstrengungen zur Bewältigung der Herausforderung Krebserkrankung ebenso aufgefordert wie die Expert/-innen. Die Früherkennung beim Zervixkarzinom ist seit Langem Bestandteil der Krebsfrüherkennungsrichtlinie und soll nun - unter Berücksichtigung der Europäischen Leitlinien - zu einem organisierten Screening weiterentwickelt, mit der teilweisen Neuorganisation der Nutzen maximiert und die Risiken minimiert werden. Vor einer flächendeckenden Implementierung ist es nötig, neue Inhalte und Organisationsstrukturen auf Machbarkeit und Eignung zu prüfen. Der Gemeinsame Bundesausschuss, in diesem Prozess nach dem Gesetzentwurf zur Umsetzung des Krebsplans führend, betont die Bedeutung der evidenzbasierten Medizin und das konkrete Zusammenwirken der Selbstverwaltungspartner für die Ergebnisfindung. Im Fachgebiet ergibt sich daran anknüpfend die Frage nach anstehendem Forschungsbedarf. Neu auszugestaltende Prozessschritte sind zu überprüfen, ob Belege für eine definierte Vorgehensweise bestehen oder erarbeitet werden müssen, z. B. das Einladungsverfahren in einer Erprobungsregelung. Die Erfahrungen aus der Umsetzung der bestehenden Früherkennungsrichtlinie sollen dabei einfließen. Eine aus dem Fachgebiet heraus initiierte Forschung könnte mit ärztlicher Kompetenz den Prozess hin zu einer für das deutsche Gesundheitssystem geeigneten Neufassung der Krebsfrüherkennungsrichtlinie fördern. 


\section{Background and Introduction}

In the last few years countries all over the world have developed national cancer plans. All of these plans were based on the recommendation issued by the WHO on the importance of developing "national cancer control programmes" [1]. Since 2008 various panels of experts have come together to work on a plan for Germany. The first National Cancer Plan for Germany was published in 2012. Now the contents need to be implemented. The framework policies need to be defined in law. The first ministry draft (Law on the Implementation of the Cancer Plan) was published in July 2012, and the government's draft legislation of a "law to promote the development of early cancer recognition and quality assurance through clinical cancer registries" (Cancer Early Detection and Cancer Registries Act, [Krebsfrüherkennungs- und -registergesetz] KFRG) was passed on August 22, 2012 [2]. In December 2012 the first hearing was held in front of the Health Commission of the German Federal Parliament. The draft is currently being reviewed in parliament.

Numerous comments by various autonomous governing bodies within the healthcare system, by the Federal Medical Association and by other interested parties have since been published, highlighting various areas where opinions diverge, the range of opinions but also those areas where a consensus could be reached. One of the areas about which there was a general consensus was the amendment to certain passages in $\S 62$ SGB V1 [Volume V of the German Social Security Code]. In the new version, early detection and compliance are no longer linked to the receipt of benefits from statutory health insurance companies; early detection of cancer is now the individual responsibility and personal choice of each citizen. The text of the draft of the KFRG reads: “... Therefore the decision of individuals to avail themselves should be guided only by sufficient, comprehensible, neutral information and counselling and by the individual's personal values and preferences and should not be influenced by incentive schemes. This corresponds to recommendations made by the Council of Europe, by the European Guidelines and by experts for the National Cancer Plan, which give priority to independent, voluntary and informed decisions regarding participation" [2]. The National Cancer Plan has made promoting health literacy a core concern: all citizens should be encouraged to take personal responsibility for participating in the national effort to deal with the challenge of cancer (as documented in the Federal Health Report [3]), and this new approach is visible in all sectors of the National Cancer Plan. Healthcare experts are similarly called upon to collaborate and contribute.

With regard to its practical implementation, the National Cancer Plan will affect those medical specialists working in areas of action where changes are planned. In gynaecology, the organisation of cervical cancer screening will be affected.

\footnotetext{
${ }^{1} \S 62$ SGB V Belastungsgrenze, ... beträgt die Belastungsgrenze 2 vom Hundert der jährlichen Bruttoeinnahmen zum Lebensunterhalt ... 2. für nach dem 1. April 1987 geborene weibliche und nach dem 1. April 1962 geborene männliche chronisch kranke Versicherte, die an einer Krebsart erkranken, für die eine Früherkennungsuntersuchung nach $\S 25$ Abs. 2 besteht, und die diese Untersuchung ab dem 1. Januar 2008 vor ihrer Erkrankung nicht regelmäßig in Anspruch genommen haben.
}

\section{Hintergrund und Einführung}

$\nabla$

Weltweit werden in den letzten Jahren nationale Krebspläne erstellt. Allen zugrunde liegt die Empfehlung der WHO zur Entwicklung von „National cancer control programmes“ [1]. Seit 2008 wurde in einer koordinierten Aktion in Expertengremien auch in Deutschland daran gearbeitet. Der erste Nationale Krebsplan wurde 2012 veröffentlicht. Seitdem stehen die Inhalte zur Umsetzung an. Die Rahmenvorgaben sollen in der Gesetzgebung festgelegt werden. Der erste Referentenentwurf (Krebsplan-Umsetzungsgesetz) wurde im Juli 2012 veröffentlicht, der Kabinettsentwurf eines „Gesetzes zur Weiterentwicklung der Krebsfrüherkennung und zur Qualitätssicherung durch klinische Krebsregister“ (Krebsfrüherkennungs- und -registergesetz, KFRG) am 22.8.2012 verabschiedet [2] Im Dezember 2012 fand die Anhörung im Gesundheitsausschuss des Bundestags statt, derzeit befindet sich der Entwurf in der parlamentarischen Diskussion.

Zahlreiche Stellungnahmen aller Partner der Selbstverwaltung, der Bundesärztekammer und aus weiteren Interessentenkreisen sind seitdem veröffentlicht worden und verdeutlichen Bereiche von divergierenden Auffassungen, deren Spannweite, aber auch Konsensfähiges. Zu Letzterem zählt beispielsweise in auffällig breitem Konsens die Änderung von Passagen des Paragrafen §62 SGB V2, der in der neuen Fassung nun Früherkennung aus der Koppelung an Pflichtigkeit über die Bindung an Leistungen aus der Gesetzlichen Krankenversicherung herausnimmt und die Krebsfrüherkennung zurückführt in die Eigenverantwortung und Selbstentscheidung der Bürgerinnen und Bürger. So heißt es dazu im Entwurf des KFRG: „... Daher sollte das Inanspruchnahmeverhalten der einzelnen Person allein durch eine ausreichende, neutrale und verständliche Information und Beratung sowie deren individuelle Werte und Präferenzen bestimmt sein und nicht durch Anreizsysteme beeinflusst werden. Dies entspricht den Empfehlungen des Rates der Europäischen Union, der Europäischen Leitlinien und der Expertinnen und Experten des Nationalen Krebsplans, welche die eigenständige, freiwillige und informierte Entscheidung über die Teilnahme in den Vordergrund stellen.“ [2] Der Nationale Krebsplan macht den Aufbau von Gesundheitsmündigkeit (Health Literacy) und das Hinführen der Bürgerinnen und Bürger zur selbstverantwortlichen Beteiligung an den nationalen Anstrengung zur Bewältigung der Herausforderung „Krebserkrankung“ (dokumentiert in der Gesundheitsberichterstattung des Bundes [3]) zu einem zentralen Anliegen, das sich durch alle Bereiche des Nationalen Krebsplans hindurchzieht.

Gleichermaßen sind die Expertinnen und Experten im Gesundheitswesen zu diesem Zusammenwirken aufgerufen.

Mit Blick auf die konkrete Umsetzung betrifft es vor allem die Fachgebiete, in deren Kompetenz die Handlungsfelder fallen, für die Veränderungen vorgesehen sind. Dazu zählt für Frauenheilkunde die Ausgestaltung der Früherkennung beim Zervixkarzinom.

\footnotetext{
§ 62 SGB V Belastungsgrenze, ... beträgt die Belastungsgrenze 2 vom Hundert der jährlichen Bruttoeinnahmen zum Lebensunterhalt ... 2. für nach dem 1.April 1987 geborene weibliche und nach dem 1. April 1962 geborene männliche chronisch kranke Versicherte, die an einer Krebsart erkranken, für die eine Früherkennungsuntersuchung nach $\S 25$ Abs. 2 besteht, und die diese Untersuchung ab dem 1. Januar 2008 vor ihrer Erkrankung nicht regelmäßig in Anspruch genommen haben.
} 


\section{What is the National Cancer Plan?}

\section{$\nabla$}

With the development of a National Cancer Plan, Germany followed the recommendations of the WHO and the EU (most recently, the conclusions of the EU Council dated 9/10 June 2008). The recommendations were fuelled by the increasing demands with regard to patient care, the increased complexity and specialisation in medicine; the necessity to improve education, training and advanced training; the need to improve interdisciplinary cooperation, quality assurance, evidence-based medicine, and patient orientation and, not least, the tendency referred to as the "chronification" of cancer. The German term "Nationaler Krebsplan" follows the commonly used international terminology (National Cancer Plan). In summary, the National Cancer Plan is a coordination and co-operation programme with a long-term perspective.

The German National Cancer Plan outlines four main areas of action and lists a number of goals:

1. Improve the early detection of cancer (Goals 1-3)

2. Improve the structure of oncological care, quality assurance and quality improvement (Goals 5-9)

3. Ensure efficient oncological treatment (with an initial focus on the provision of oncological drugs) (Goal 10)

4. Strengthen patient orientation (Goals 11-13)

Goal 2a "Organised cervical cancer screening" in area of action 1: "Improve the early detection of cancer" aims to reorganise cervical cancer screening in Germany.

\section{Legislation on the Implementation of the National Cancer Plan \\ $\nabla$}

The implementation of the National Cancer Plan will be codified in law. The government's draft legislation dated August 2012 formulated a conceptual framework together with a number of measures outlined below "with regard to improving the early detection of cancer":

- The maximum number of times persons can demand cancer screening and the age limits for cancer screening will no longer be mandated in law; instead, in future they will be determined by the Federal Joint Committee (Gemeinsamer Bundesausschuss [G-BA]) based on the current state of medical knowledge.

- Cancer screening procedures already covered by an existing European guideline (published by the European Commission) on quality assurance for this cancer screening programme should be carried out as organised cancer screening programmes. Currently - in addition to the established programme of mammography screening - this applies to screening for cervical cancer and for bowel cancer.

- The G-BA has the duty ... to decide on the contents and organisational structure of organised cancer screening programmes for cervical cancer and bowel cancer which will take account of the relevant European guidelines. The Committee will additionally be given the possibility to verify the appropriateness of various contents and organisational structures of organised cancer screening programmes. ...

Many of these aspects are currently being reviewed and discussed. In all cases, the Federal Joint Committee (G-BA) will play a key role in formulating requirements. The G-BA is the highest

\section{Was beinhaltet der Nationale Krebsplan?}

\section{$\nabla$}

Mit der Entwicklung eines Nationalen Krebsplans folgte Deutschland den Empfehlungen von WHO und EU (zuletzt EU-Ratsschlussfolgerungen vom 9./10. Juni 2008). Steigende Anforderungen an die Versorgung, zunehmende Komplexität und Spezialisierung, Aufgaben wie Aus-, Weiter- und Fortbildung, Interdisziplinarität, Qualitätssicherung, Evidenzbasierung, Patientenorientierung und nicht zuletzt die Tendenz, die als „Chronifizierung“ der Krebserkrankung bezeichnet wird, bilden den Hintergrund. Der Titel „Nationaler Krebsplan" orientiert sich an der inzwischen international üblichen Terminologie (National Cancer Plan). In der Summe ist es ein Koordinierungs- und Kooperationsprogramm mit langjähriger Perspektive.

Vier Handlungsfelder zeigt der Nationale Krebsplan auf und benennt Ziele:

1. Weiterentwicklung der Krebsfrüherkennung (Ziele 1-3)

2. Weiterentwicklung der onkologischen Versorgungsstrukturen und der Qualitätssicherung und Qualitätsförderung (Ziele 5-9)

3. Sicherstellung einer effizienten onkologischen Behandlung (zunächst Schwerpunkt auf onkologischer Arzneimittelversorgung) (Ziel 10)

4. Stärkung der Patientenorientierung (Ziele 11-13)

Das Ziel 2a „Organisiertes Zervixkarzinom-Screening“ im Handlungsfeld 1: „Weiterentwicklung der Krebsfrüherkennung“ zielt ab auf die Umgestaltung der Krebsfrüherkennung in Deutschland.

\section{Gesetzgebung zur Umsetzung des Nationalen Krebsplans

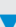

Ein Gesetz soll die Umsetzung des Nationalen Krebsplans verankern. Der Kabinettsentwurf vom August 2012 formuliert dazu einen konzeptionellen Rahmen und folgende Maßnahmen „in Bezug auf die Weiterentwicklung der Krebsfrüherkennung“:

- Die maximale Häufigkeit der Inanspruchnahme und die Altersgrenzen der Krebsfrüherkennungsuntersuchungen werden nicht länger gesetzlich vorgegeben, sondern künftig durch den Gemeinsamen Bundesausschuss (G-BA) nach dem jeweils gültigen Stand des medizinischen Wissens festgelegt.

- Krebsfrüherkennungsuntersuchungen, für die von der Europäischen Kommission veröffentlichte Europäische Leitlinien zur Qualitätssicherung von Krebsfrüherkennungsprogrammen vorliegen, sind als organisierte Krebsfrüherkennungsprogramme durchzuführen. Dies betrifft derzeit - neben dem bereits eingeführten Mammografie-Screening - die Früherkennungsuntersuchungen für Gebärmutterhalskrebs und für Darmkrebs.

- Der G-BA wird verpflichtet ... die inhaltliche und organisatorische Ausgestaltung organisierter Krebsfrüherkennungsprogramme für Gebärmutterhalskrebs und Darmkrebs unter Berücksichtigung der einschlägigen Europäischen Leitlinien zu beschließen. Er erhält außerdem die Möglichkeit zur Erprobung der geeigneten inhaltlichen und organisatorischen Ausgestaltung organisierter Krebsfrüherkennungsprogramme....

Hieraus stehen zahlreiche Aspekte in der aktuellen Diskussion. In jedem Fall wird der Gemeinsame Bundesausschuss (G-BA) eine zentrale Rolle in der Ausgestaltung spielen. Der G-BA ist das oberste Beschlussgremium der gemeinsamen Selbstverwaltung der Ärzte, Zahnärzte, Psychotherapeuten, Krankenhäuser und Krankenkassen in Deutschland. Er bestimmt in Form von Richtlinien den Leistungskatalog der Gesetzlichen Krankenversicherung (GKV) für mehr als 
decision-making body for the autonomous governing bodies of physicians, dentists, psychotherapist, hospitals and health insurance companies in Germany. In its guidelines, the G-BA decides on the catalogue of benefits provided by statutory health insurance to more than 70 million insured persons in Germany and thus determines which healthcare benefits and services will be reimbursed in statutory healthcare. In addition, the G-BA decides on quality assurance measures for outpatient and inpatient healthcare [4].

The draft bill mentioned above also clarifies the specific steps needed to implement an objective, for example for the area of action 1 "Improve the early detection of cancer": "the goal is to provide better information about the benefits and risks of cancer screening ... and make existing screening for cervical cancer and bowel cancer more effective by improving the invitation procedure, quality assurance measures and the measurement of outcomes."

\section{Goal 2a of Area of Action 1 of the National Cancer Plan: Reorganisation of Cervical Cancer Screening \\ $\nabla$}

Early detection of cervical cancer has been an integral part of the Directive for the Early Detection of Cancer since many years and will now be developed further to take account of the European guideline. Intention of this reorganisation is to maximise the benefits of early detection and minimise the risks. This would involve the organisational development and partial reorganisation of the current cervical cancer early detection programme.

The European guideline also lists certain elements characteristic for population-based organised screening programmes; they include precise regulations governing procedures, defined structures, an organisational team to support screening (e.g. on a regional basis), and a procedure to determine the burden of disease in the general population [5]. Cancer screening procedures already covered by an existing European guideline published by the European Commission should be made available in the form of organised screening programmes. Implementation of an "organised cancer screening programme" must therefore

- include regular invitations to insured persons to attend screening,

- provide detailed information to insured persons,

- must take account of recommendations in the European guidelines with regard to the examination method used, the age limit, the intervals between screening, and the investigation of any abnormal findings,

- must take account of the recommendations on quality assurance in European guidelines, and

- ensure the systematic recording of results, monitor outcomes and the improvement of quality.

Thus, an organised screening programme will require regulations on procedures (screening policy), together with a team to implement the regulations, organise the provision of care, and ensure that quality assurance measures are in place as well as the necessary structures for quality control and evaluation. The questions which arise will then be: which elements need to be added to the statutory early detection programme currently existing in Germany, which elements need to be improved and developed further, and what they should look like in practice, in order for these programmes to fulfil the basic goal behind these changes: that of maximising benefits and minimising risks.
70 Millionen Versicherte und legt damit fest, welche Leistungen der medizinischen Versorgung von der Gesetzlichen Krankenversicherung (GKV) erstattet werden. Darüber hinaus beschließt der G-BA Maßnahmen der Qualitätssicherung für den ambulanten und stationären Bereich des Gesundheitswesens [4].

Der o.g. Gesetzentwurf konkretisiert auch Schritte zur Realisierung der Zielsetzung, so beispielsweise zum Handlungsfeld 1, „Die Weiterentwicklung der Krebsfrüherkennung“: „Ziele sind, besser über Nutzen und Risiken der Krebsfrüherkennung zu informieren, ... und die bestehende Früherkennung von Gebärmutterhalskrebs und von Darmkrebs durch Einladungsverfahren, Qualitätssicherung und Erfolgskontrollen wirksamer zu machen."

\section{Ziel 2a im Handlungsfeld 1 des Nationalen Krebsplans: Umgestaltung der Krebsfrüherkennung beim Zervixkarzinom \\ $\nabla$}

Die Früherkennung beim Zervixkarzinom ist bereits seit vielen Jahren Bestandteil der Krebsfrüherkennungsrichtlinie und soll nun unter Berücksichtigung der Europäischen Leitlinien weiterentwickelt werden. Durch ein organisiertes Screening, so das Anliegen, sollen der Nutzen des Screenings maximiert und die Risiken minimiert werden. Dies beinhaltet insbesondere eine organisatorische Weiterentwicklung und teilweise Neuorganisation der derzeit etablierten Zervixkarzinom-Früherkennung.

In den Europäischen Leitlinien werden Elemente benannt, die ein bevölkerungsbezogen organisiertes Screening charakterisieren, dazu zählen: genaue Verfahrensvorschrift, definierte Strukturen, ein das Screening unterstützendes Organisationsteam (z.B. regional), und ein Verfahren zur Bestimmung der Krankheitslast in der Bevölkerung [5]. Krebsfrüherkennungsuntersuchungen, für die es von der Europäischen Kommission veröffentlichte Europäische Leitlinien gibt, sollen als organisierte Früherkennungsprogramme angeboten werden. Die Durchführung eines „organisierten Krebsfrüherkennungsprogramms“ beinhaltet danach insbesondere

- die regelmäßige Einladung der Versicherten,

- umfassende Information der Versicherten,

- Berücksichtigung der Empfehlungen der Europäischen Leitlinien hinsichtlich Untersuchungsmethode, Altersgrenzen, Untersuchungsintervall, Abklärung auffälliger Befunde und

- Berücksichtigung der Empfehlungen der Europäischen Leitlinien hinsichtlich der Qualitätssicherung,

- systematische Erfassung, Überwachung und Verbesserung der Qualität.

Gemäß diesem Verständnis braucht man für ein organisiertes Screening Verfahrensvorschriften (screening policy), ein Team, das die Vorschriften umsetzt, Versorgung organisiert und Qualitätssicherung gewährleistet, sowie Strukturen zur Qualitätssicherung und Evaluation. Daraus ergibt sich die Frage, welche Elemente zum derzeit nach gesetzlicher Vorgabe in Deutschland bestehenden Früherkennungsprogramm ergänzt werden sollten, welche einer Weiterentwicklung bedürfen und wie diese konkret aussehen soll, um dem hinter den Änderungen stehenden grundlegenden Anliegen zu entsprechen: Nutzen maximieren, Risiken minimieren. 


\section{Cancer Screening in Germany as Defined in the Guidelines of the G-BA \\ $\nabla$}

The yardstick against which changes to screening concepts based on recommendations in the European guidelines should be measured is the extent to which these changes will reduce the burden of disease (mortality/incidence) and the potential for damage (false positive findings, over-diagnosis, over-treatment, lulling into a false sense of security because of false negative findings) and whether these changes will make healthcare in Germany more cost-effective. This means that at the very latest (if not before) when screening concepts are being amended, the G-BA must also examine which parts of the European guideline are suited to being incorporated or adapted for use in Germany.

Before comprehensively implementing an organised screening programme in accordance with SGB V [Volume V of the German Social Security Code] § 25 Abs. 6 (as was suggested in the draft legislation), it will be necessary to examine the new contents and organisational structures, for example, the process used to invite persons to attend screening or the measures used for quality assurance, with regard to their feasibility, suitability, effectiveness and cost. A pilot study should be carried out prior to implementing any big changes to investigate the feasibility, effectiveness and cost. "Suitability" also includes examining and, if necessary, adapting requirements of the European guideline to the patient care conditions in Germany. In the current draft legislation, the Federal Joint Committee (G-BA) is responsible for "drawing up a directive which will define the content, data flow, reimbursement and scientific evaluation of a feasibility study."

Consequently, the draft legislation envisages the possibility of a trial scheme to test newly developed elements of an organised cancer screening programme. If the Federal Joint Committee concludes that the necessary information regarding the appropriate content and organisation of an organised cancer screening programme is not yet available, for example with regard to the best way of inviting persons for screening, it can draw up a directive for a trial scheme in accordance with $\S 137$ e SGB V (Trials of research methods and methods of treatment) to obtain the findings necessary to develop the content matter and organisation of a new screening programme. The time required to prepare, implement and evaluate the trial scheme should not exceed a period of 5 years.

The G-BA being the prime actor, will include the autonomous governing bodies of the German healthcare system represented in the Joint Federal Committee. The G-BA has emphasised the importance of evidence-based medicine as the basis for action and stated that co-operation between the various autonomous governing bodies of the healthcare system is indispensable to obtain viable results. The advisory opinion of the G-BA given in the hearing on July 24, 2012 states: "besides, the task of improving early cancer detection in Germany can only be resolved in practice by the affected autonomous governing bodies of the healthcare system. The responsibility for fleshing out the possible scope of action must therefore rightly lie with the autonomous governing bodies. The existing commitment to evidence-based medicine as the yardstick for content thus complies with the requirements of constitutional law". [6]

For Germany the initial focus on content will presumably be in the areas of action listed below. All of these areas will require the participation of and contributions by the autonomous governing bodies of the German healthcare system (the respective representatives of the bodies representing physicians with their own practice,

\section{Krebsfrüherkennung wird in Deutschland in Richtlinien des G-BA definiert \\ $\nabla$}

Eine geänderte Screening-Konzeption muss sich letztendlich daran messen lassen, inwieweit mit den Empfehlungen der Europäischen Leitlinie eine Senkung der Krankheitslast (Mortalität/Inzidenz) und des Schadenspotenzials (falsch positive Befunde, Überdiagnostik, Übertherapie, Vermittlung einer falschen Sicherheit durch falsch negative Befunde) sowie eine kosteneffektivere Versorgung unter deutschen Rahmenbedingungen erreicht werden kann. Das bedeutet, dass spätestens im Rahmen des Verfahrens (wenn nicht bereits vorab) durch den G-BA auch zu prüfen ist, welche Anteile der Europäischen Leitlinie für eine Übernahme bzw. Anpassung geeignet sind. Vor einer flächendeckenden Implementierung eines organisierten Früherkennungsprogramms nach SGB V, § 25 Abs. 6 (so der Entwurf) ist es notwendig, neue Inhalte und Organisationsstrukturen, wie z. B. Einladungsverfahren oder Qualitätssicherungsmaßnahmen hinsichtlich Machbarkeit, Eignung, Effektivität und Kosten zu prüfen. Es sollte vor größeren Veränderungen zunächst eine Pilotstudie erfolgen, um die Machbarkeit, Effektivität und Kosten zu prüfen. Der Aspekt „Eignung“ umfasst z.B. auch die Prüfung und ggfs. Anpassung der Aussagen der Europäischen Leitlinie in Bezug zu der Versorgungssituation in Deutschland. Nach dem bisherigen Entwurf soll der Gemeinsame Bundesausschuss schließlich „in einer Richtlinie Inhalte, Datenflüsse, Vergütung und wissenschaftliche Begleitung der Machbarkeitsprüfung festlegen“.

Folgerichtig sieht der Gesetzentwurf die Möglichkeit einer Erprobung der Ausgestaltung von organisierten Krebsfrüherkennungsprogrammen vor: Gelangt der Gemeinsame Bundesausschuss zu der Feststellung, dass notwendige Erkenntnisse über die geeignete inhaltliche und organisatorische Ausgestaltung des jeweiligen organisierten Krebsfrüherkennungsprogramms noch nicht vorliegen, z. B. hinsichtlich des Einladungsverfahrens, kann er eine Richtlinie zur Erprobung entsprechend § 137e SGB V (Erprobung von Untersuchungs- und Behandlungsmethoden) beschließen, um die notwendigen Erkenntnisse für die inhaltliche und organisatorische Ausgestaltung zu gewinnen. Der Zeitraum der Vorbereitung, Durchführung und Auswertung der Erprobung soll 5 Jahre nicht überschreiten.

Ist als zentral Handelnder der G-BA vorgesehen, schließt dies auch die in ihm in gemeinsamer Gremienarbeit tätigen Selbstverwaltungspartner ein. Der G-BA stellt seinerseits die Bedeutung der evidenzbasierten Medizin als handlungsleitend und das konkrete Zusammenwirken der Partner als unabdingbar für die Ergebnisfindung heraus. So heißt es in der Stellungnahme des G-BA in der Anhörung am 24. Juli 2012: „Im Übrigen wird die Aufgabe der Verbesserung der Krebsfrüherkennung in Deutschland zweckmäßig nur durch die betroffenen Partner des Gesundheitswesens gelöst werden können. Die Zuständigkeit für die Ausfüllung des danach möglichen Gestaltungsspielraums ist demgemäß richtigerweise bei der Selbstverwaltung zu verorten. Bereits die bestehende Festlegung auf den inhaltlichen Maßstab der evidenzbasierten Medizin stellt insoweit die Einhaltung der Vorgaben des Verfassungsrechts sicher“. [6]

Für Deutschland zeichnen sich inhaltlich voraussichtlich die folgenden Bereiche als vorrangige Handlungsfelder ab, bei denen die Kompetenz der Selbstverwaltungspartner (jeweilige Vertretung von niedergelassener Ärzteschaft, Krankenhäusern und Krankenkassen, aber auch weiterer im G-BA Beteiligter) benötigt und einzubeziehen ist:

- Einladungsverfahren, das bisher nicht bevölkerungsbezogen geregelt ist

- Umfassende Information der mit der Maßnahme anzusprechenden Bürgerinnen und Bürger (bisher nicht zentral festgelegt) 
hospitals and health insurance companies but also other bodies represented in the $G-B A$ ). Areas of action include

- the procedure used to invite persons for screening, a procedure hitherto not regulated for the general population

- the detailed information to be provided to persons invited for screening (hitherto not centrally specified)

- the evaluation of individual procedural steps and the comparison of these steps with the recommendations given in the European guidelines (reasons for diverging from the European guidelines need to be stated and justified, and these reasons must be comprehensible; the suitability of amendments to optimise currently existing procedures in Germany must also be documented.)

- a revision of the quality concept

transparency regarding quality

- integration of procedures in an organisation concept ("screening policy")

An organised screening programme for cervical cancer is a multistage process with a succession of process steps which build on one another [21,22]. The success of any subsequent step also depends on the appropriateness (with respect to concept, organisation and implementation) of the preceding steps.

For gynaecology, the question which follows on from that is the question regarding which areas will need more research in future. The process steps developed for a screening programme must be evaluated to see whether there is clear evidence which supports an already existing established mode of approach (national/international) or whether the approach still needs to be developed further. (The transferability of results from other countries which have other screening conditions must be considered separately; nevertheless, proposals for different concepts, strategic considerations and "lessons learnt" need to be taken into account.)

This includes, among other things,

- identifying the target population (Who? When? How often?) $[7,8]$

- the implications of introducing of HPV vaccination

- the procedure for inviting women for screening and providing information to women entitled to screening

- the administration of the Pap test

- the findings of the Pap test and documentation of findings

- informing women who have normal findings and the date of their follow-up examination [9]

- summoning women with unusable findings for a repeat examination

- the care of women with abnormal findings (diagnostics, treatment where required, a fail-safe system, but also a review of the problem of over-/under-treatment in women with CIN) [10]

- the long-term consequences of false negative/false positive findings and subsequent interventions [11]

- registration, monitoring and evaluation [12]

A theoretical (research) and practical investigation of unanswered issues initiated by gynaecologists prior to the investigation of these issues by the various autonomous governing bodies could facilitate the process and even lead the way for a revision of the guideline on cancer screening. The key issues are those previously listed in the reports by the Institute for Quality and Efficiency in Healthcare (Institut für Qualität und Wirtschaftlichkeit im Gesundheitswesen [IQWIG]) [13] and the Agency for Healthcare Research und Quality Research (AHRQ) [14] published at
- Bewertung der einzelnen Verfahrensschritte im Abgleich mit Empfehlungen der Europäischen Leitlinie (Abweichungen von den Europäischen Leitlinien sollen fachlich begründet und nachvollziehbar sei, andererseits auch die Eignung im Sinne der Optimierung des in Deutschland etablierten Vorgehens belegt sein.)

- Überarbeitung des Qualitätskonzepts

- Qualitätstransparenz

- Zusammenfassung in einem Organisationskonzept („screening policy“)

Ein organisiertes Zervixkarzinom-Screening wird als mehrstufiger Prozess mit einer Abfolge von aufeinander aufbauenden Prozessschritten zu betrachten sein $[21,22]$. Der Erfolg der nachfolgenden Schritte ist dabei auch abhängig von der Angemessenheit (in Konzept, Organisation und Durchführung) des/der Vorausgehenden.

Im Fachgebiet ergibt sich daran eng anknüpfend die Frage nach anstehendem Forschungsbedarf: Die für ein Screening-Verfahren zu gestaltenden Prozessschritte sind daraufhin zu prüfen, inwieweit eindeutige Belege für eine definierte Vorgehensweise bereits bestehen (national/international) oder erst erarbeitet werden müssen. (Die Übertragbarkeit der Ergebnisse aus anderen Ländern unter anderen Screening-Bedingungen ist dabei stets gesondert zu erwägen, gleichwohl verdienen konzeptionelle Anregungen, strategische Überlegungen und „lessons learnt“ in jedem Fall Beachtung.)

Dazu zählen u.a.

- Identifikation der Zielpopulation (Wer? Wann? Wie oft?) [7,8]

- Implikationen aus der Einführung der HPV-Impfung

- Einladungsprozess und Information der anspruchsberechtigten Frauen

- Abstrichentnahme

- Befundung der Abstriche und Dokumentation

- Information der Frauen mit normalen Befunden und Termin der Folgeuntersuchung [9]

- Wiedereinbestellung der Frauen mit nicht verwertbaren Abstrichen

- Weiterbetreuung der Frauen mit auffälligen Befunden (Diagnostik, ggf. Behandlung, „fail-safe-system“, auch z.B. Klärung des Problemfelds Über-/Untertherapie bei CIN) [10]

- Langzeitfolgen aus falsch negativen/falsch positiven Befunden und konsekutiven Interventionen [11]

Registrierung, Monitoring und Evaluation [12]

Die noch vor einer Zusammenarbeit in den Gremien der Selbstverwaltung aus dem Fachgebiet heraus initiierte Prüfung und Untersuchung offener Fragen in Modellen und begleitender Forschung könnten den Prozess hin zu einer Neufassung der Krebsfrüherkennungsrichtlinie fachlich schienen und fördern. Als zentrale Anliegen stehen besonders die offenen Fragen im Raum, die sich aus den zu Jahresbeginn 2012 veröffentlichten Gutachten des Instituts für Qualität und Wirtschaftlichkeit im Gesundheitswesen (IQWIG) [13] und der Agency for Healthcare Research und Quality Research (AHRQ) [14] zur Wertigkeit einzelner Schritte im Rahmen eines Zervixkarzinom-Screenings ergeben: es fehlen Studien, welche die Nutzen-Schadens-Bilanz erhellen. Voraussetzung für jeglichen Screening-Ansatz ist jedoch die grundlegende Prüfung anhand von Kriterien - erstmals zusammengestellt in einem WHO-Bericht 1968 [15] „Principles and Practices of Screening for Diseases“ und 2002 [16] aktualisiert. Die Kriterien zielen ab auf die Angemessenheit von Screening-Programmen und orientieren sich insbesondere daran, dass das Überwiegen des Nutzens belegt ist. Diese Bewertung hat physische und psychische Implikationen gleichermaßen einzubeziehen. Außerdem soll vorab geklärt sein, inwieweit die Einrichtungen und Ressourcen 
the beginning of 2012 on the value and role of various steps in a cervical cancer screening programme: the fact that studies which would shed more light on the benefits and risks are lacking. The precondition for any screening programme must be an investigation based on various criteria - as compiled for the first time in the WHO report "Principles and Practices of Screening for Diseases" published in 1968 [15] and updated in 2002 [16]. These criteria focus on the suitability of screening programmes and the necessity to prove that the benefits will outweigh the drawbacks. Evaluations must include both physical and psychological implications. It will be necessary to clarify in advance whether sufficient facilities and resources (expertise, staff, premises and financial means) are available to meet the demand for care, i.e. screening-associated activities and any consequent demands such as operative procedures, follow-up examinations, etc.

The draft legislation cites the procedure used to invite women for screening as an example of an area where the new possibility of a trial scheme as outlined in $\S 137$ e SGB V (Trials of research methods and methods of treatment) could be used. For the German healthcare system, the experience gained out of the current early detection scheme will be very important when developing new regulations for screening trial schemes. Gynaecologists and other key policy makers have rightly pointed to various important successes achieved with the current guideline [17]. Only after the appropriate steps have been taken, including a systematic investigation [18] and trial schemes, will it be possible to summarise all the findings and create a new, appropriate and responsible organised screening programme (screening policy).

\section{Conclusion}

\section{$\nabla$}

In the upcoming discussions on the design of an evidence-based screening programme, it is important to remember that, despite all measures taken to detect and prevent cancer, the priority must be to ensure that access to screening is low threshold and that screening is accessible to [19] and accepted by the target group [20]. Gynaecologists need to start by defining those areas which require more research prior to their implementation into a new version of the cancer screening guideline by the G-BA by considering the necessary steps of an organised screening and their course, also by rolling out trial schemes as outlined in $\S 137$ e SGB V. This would allow gynaecologists to offer proposals which meet with general consensus and to promote a process based on medical expertise which will offer solutions and amendments adapted to suit the German healthcare system.

\section{Conflict of Interest}

\section{$\nabla$}

None.

\footnotetext{
Affiliations

${ }^{1}$ Institut für Frauengesundheitsforschung, Universitätsfrauenklinik Tübingen, Tübingen

2 Institut für Frauengesundheitsforschung, Universitätsfrauenklinik Tübingen, Tübingen

${ }^{3}$ Frauenklinik, Universitätsklinikum, Erlangen

${ }^{4}$ Caritas Krankenhaus St. Josef, Universität Regensburg, Regensburg

${ }^{5}$ Berufsverband der Frauenärzte, Hannover

${ }^{6}$ Institut für Frauengesundheitsforschung, Universitätsfrauenklinik, Tübingen
}

(Kompetenz, personell, räumlich und finanziell) verfügbar sind, welche die Versorgungsbedarfe, d.h. Screening-assoziierte Aktivitäten selbst und nachfolgender Bedarf wie operative Maßnahme, Folgeuntersuchungen etc. decken.

Im Gesetzentwurf ist das Einladungsverfahren als Beispiel eines Bereichs aufgeführt, bei dem die neue Möglichkeit einer Erprobungsregelung entsprechend § 137e SGB V (Erprobung von Untersuchungsund Behandlungsmethoden) zum Tragen kommen könnte. Bei der Erarbeitung solcher Erprobungsregelungen sind die Erfahrungen aus der Umsetzung der bisherigen Früherkennungsrichtlinie für das deutsche Gesundheitssystem von großer Bedeutung. Zu Recht wird vonseiten der niedergelassenen Frauenärzt/-innen und weiteren Kompetenzträger/-innen auf wichtige Erfolge des Verfahrens auf der Grundlage der noch geltenden Richtlinie hingewiesen [17]. Erst nach entsprechenden Schritten von systematischer Klärung [18] und Erprobung kann die Zusammenfassung zu einem weiterentwickelten Verfahren nach Art eines organisierten Screenings (screening policy) sachgemäß und verantwortungsvoll erfolgen.

\section{Schlussfolgerungen \\ $\nabla$}

Bei den anstehenden Diskussionen zur Ausgestaltung, die sich insbesondere an Evidenz zu orientieren hat, ist grundlegend zu berücksichtigen, dass bei allen Maßnahmen der Früherkennung und Vorsorge die Niederschwelligkeit und Zugänglichkeit [19] des Angebots und die Akzeptanz durch die Zielgruppe zu den Prämissen zählen [20]. Entlang des Ablaufs und der Schritte, die der Prozess der Früherkennung - dann in der Organisation eines Screenings - nehmen soll, sollten im Fachgebiet zunächst die Bereiche definiert werden, die in Vorbereitung auf die definierende Umsetzung in eine Neufassung der Krebsfrüherkennungsrichtlinie durch den G-BA wissenschaftlicher Zuwendung bedürfen, u.a. auch in Erprobungen nach den Regelungen in § 137e SGB V. Dies würde eine konsentierte Antwort des Fachgebiets ermöglichen und einen durch ärztliche fachliche Kompetenz geleiteten Prozess unterstützen, hin zu für das deutsche Gesundheitssystem passgerechten Änderungen und Lösungen.

\section{Interessenkonflikt}

$\nabla$

Nein.

\section{References}

1 WHO. National cancer control programmes. 2012. http://www.who. int/cancer/nccp/en/; last access: 17.10.2012

2 Bundesministerium für Gesundheit (BMG). Laufende Gesetzgebungsund Verordnungsverfahren. Entwurf eines Gesetzes zur Weiterentwicklung der Krebsfrüherkennung und zur Qualitätssicherung durch klinische Krebsregister (Krebsfrüherkennungs- und -registergesetz KFRG) (Stand: Kabinettbeschluss 22.8.2012). http://www.bmg.bund. de/fileadmin/dateien/Downloads/Gesetze_und_Verordnungen/ Laufende_Verfahren/K/Krebsregister/Entwurf_eines_Gesetzes_zur_ Weiterentwicklung_der_Krebsfrueherkennung_und_zur_ Qualitaetssicherung_durch_klinische_Krebsregister.pdf; last access: 28.1.2013

3 Robert Koch-Institut; die Gesellschaft der epidemiologischen Krebsregister in Deutschland e.V., Hrsg. Krebs in Deutschland 2007/2008. 8. Ausgabe. Berlin: Robert Koch-Institut; 2012 
4 Gemeinsamer Bundesausschuss (G-BA). http://www.g-ba.de/; last access: 22.10 .2012

5 European Commission. European guidelines for quality assurance in cervical cancer screening. 2nd ed. 2008. http://bookshop.europa.eu/ en/european-guidelines-for-quality-assurance-in-cervical-cancerscreening-ptND7007117/; last access: 28.2.2013

6 G-BA. Stellungnahme des Gemeinsamen Bundesausschusses zum Entwurf eines Gesetzes zur Umsetzung von Empfehlungen des Nationalen Krebsplans (Krebsplan-Umsetzungsgesetz). Anhörung am 24. Juli 2012. http://www.g-ba.de/downloads/17-98-3291/2012-07-24_SN_ G-BA_Krebsplan-Umsetzungsgesetz.pdf; last access: 22.10.2012

7 Sasieni P, Castanon A. Effectiveness of cervical screening with age: population based case-control study of prospectively recorded data. BMJ 2009; 339: b2968

8 Andrae B, Strander B, Silfverdal L et al. Benefit of cervical cancer screening in young women - a matter of adherence to the recommended screening interval. Response to Sasieni et al. BMJ 2009; 339: b2968

9 Lönnberg SV, Anttila A, Luostarinen T et al. Age-specific effectiveness of the Finnish cervical cancer screening programme. Cancer Epidemiol Biomarkers Prev 2012; DOI: 10.1158/1055-9965.EPI-12-0162

10 Andrae B, Andersson TM, Lambert PC et al. Screening and cervical cancer cure: population based cohort study. BMJ 2012; 344: e900

11 Schiffman M, Castle PE, Jeronimo J et al. Human papillomavirus and cervical cancer. Lancet 2007; 370: 890-907

12 Campbell NC, Murray E, Darbyshire J et al. Designing and evaluating complex interventions to improve health care. BMJ 2007; 334: 455459

13 IQWIG. [S10-01] Nutzenbewertung des HPV-Tests im Primärscreening des Zervixkarzinoms. 1/2012. https://www.iqwig.de/s10-01nutzenbewertung-des-hpv-tests-im.986.html?tid=1267\&phlex override_command=element\&random=ceadc2; last access: 22.10 .2012
14 Agency for Healthcare Research and Quality; U.S. Department of Health and Human Services. Screening for cervical cancer. 3/2012. http:// www.uspreventiveservicestaskforce.org/uspstf/uspscerv.htm; last access: 22.10 .2012

15 Wilson JMG, Jungner G. Principles and practice of screening for disease. WHO Chronicle. Public Health Papers, \#34. Geneva: World Health Organization 1968; 22: 473

16 Brindle P, Fahey T. Primary prevention of coronary heart disease. BM] 2002; 325: 56-57

17 BMG. Ziele-Papiere. Darin: Vortrag von Dr. Dominik Dietz (BMG) am 2.3.2010 im Rahmen des Workshops zum Thema „ZervixkarzinomScreening“ des BMG in Bonn. http://www.bmg.bund.de/fileadmin/ dateien/Downloads/N/Nationaler_Krebsplan/Ziele_Papier_2a_ Weiterentwicklung_Zervixkarzinom_Screening.pdf; last access: 28.1.2013

18 Spix C, Blettner M. Screening. Part 19 of a series on evaluation of scientific publications. Dtsch Arztebl Int 2012; 109: 385-390

19 Simoes E, Brucker S, Wallwiener D. Werden Zentren ihrem Auftrag (noch) gerecht? Geburtsh Frauenheilk 2012; 72: 893-897

20 Lofters AK, Moineddin R, Hwang SW et al. Does social disadvantage affect the validity of self-report for cervical cancer screening? Int J Womens Health 2013; 5: 29-33

21 Ziemke P. Predictive value of class III D cytological diagnosis (Munich II, low and moderate dysplasia) and additional high-risk HPV testing. Geburtsh Frauenheilk 2012; 72: 622-629

22 Jentschke M, Soergel P, Hillemanns P. Importance of HPV genotyping for the screening, therapy and management of cervical neoplasias. Geburtsh Frauenheilk 2012; 72: 507-512 